\title{
Is allergy to peanuts and nuts a predictive factor for asthma development?
}

\author{
Mirjana Zivanovic ${ }^{1 *}$, Marina Atanaskovic-Markovic ${ }^{2}$ \\ From Food Allergy and Anaphylaxis Meeting 2014 \\ Dublin, Ireland. 9-11 October 2014
}

\section{Introduction}

Food allergy is an immunologically mediated adverse reaction to food. Peanuts and nuts are common cause of food allergy in both children and adults, and clinical picture may be serious and life threatening. This type of food allergy persists for entire life, while cross-reactivity is not uncommon due to homology among most nut allergens.

\section{Aim}

The aim of this paper was to determine the significance of peanut and nuts allergy in asthma development.

\section{Material and methods}

The aim of the research was analyzed on a sample of 208 children aged between 6 months and 6 years who were evaluated to food allergens. Each child underwent skin prick test, prick to prick test and specific IgE testing.

\section{Results}

The total sample included 105 boys and 103 girls. Peanut allergy was present in $37(17.79 \%)$ and nuts allergy in $32(15.38 \%)$ of children. Positive family history to atopy was present in $52 \%$ and positive personal history in $54 \%$ of cases. Asthma developed in 30 (81.08\%) children allergic to peanuts and $24(75 \%)$ children allergic to nuts.

\section{Conclusion}

Peanut allergy is a predictive factor for asthma development; however, the effects of positive personal and family history must not be underestimated.

${ }^{1}$ Special Hospital for Lung Diseases, Sokobanja, Serbia

Full list of author information is available at the end of the article

\author{
Authors' details \\ ${ }^{1}$ Special Hospital for Lung Diseases, Sokobanja, Serbia. ${ }^{2}$ Faculty of Medicine, \\ University of Belgrade, University Children's Hospital, Belgrade, Serbia.
}

Published: 30 March 2015

doi:10.1186/2045-7022-5-S3-P168

Cite this article as: Zivanovic and Atanaskovic-Markovic: Is allergy to peanuts and nuts a predictive factor for asthma development? Clinical and Translational Allergy 2015 5(Suppl 3):P168.

Submit your next manuscript to BioMed Central and take full advantage of:

- Convenient online submission

- Thorough peer review

- No space constraints or color figure charges

- Immediate publication on acceptance

- Inclusion in PubMed, CAS, Scopus and Google Scholar

- Research which is freely available for redistribution

Submit your manuscript at www.biomedcentral.com/submit
() Biomed Central

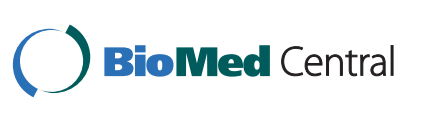

(c) 2015 Zivanovic and Atanaskovic-Markovic; licensee BioMed Central Ltd. This is an Open Access article distributed under the terms of the Creative Commons Attribution License (http://creativecommons.org/licenses/by/4.0), which permits unrestricted use, distribution, and reproduction in any medium, provided the original work is properly cited. The Creative Commons Public Domain Dedication waiver (http://creativecommons.org/publicdomain/zero/1.0/) applies to the data made available in this article, unless otherwise stated. 